\title{
Long-term changes on estuarine ciliates linked with modifications on wind patterns and water turbidity
}

López-Abbate M. Celeste ${ }^{1,{ }^{*}}$, Molinero Juan-Carlos ${ }^{2}$, Perillo Gerardo M.E. ${ }^{1}$, Barría De Cao M. Sonia ${ }^{1}$, Pettigrosso Rosa E. ${ }^{3}$, Guinder Valeria A. . , Uibrig Roman ${ }^{1}$, Berasategui Anabela A. ', Vitale Alejandro ${ }^{1}$, Marcovecchio Jorge E. ${ }^{1,4,5}$, Hoffmeyer Mónica S. ${ }^{1}$

${ }^{1}$ Instituto Argentino de Oceanografía (CONICET-UNS), Camino La Carrindanga Km 7.5, 8000, Bahía Blanca, Argentina

${ }^{2}$ Institut de Recherche pour le Développement (IRD), UMR248 MARBEC, IRD/CNRS/IFREMER/UM, Sète Cedex, France

${ }^{3}$ Departamento de Biología, Universidad Nacional del Sur, Av. Alem 1253, 8000, Bahía Blanca, Argentina

${ }^{4}$ Universidad Tecnológica Nacional, Facultad Regional Bahía Blanca (UTN-BHI), 11 de Abril 461, 8000, Bahía Blanca, Argentina

${ }^{5}$ Universidad FASTA, Facultad de Ingeniería, Gascón 3145, 7600, Mar del Plata, Argentina

*Corresponding author : Celeste M. López-Abbate, email address : $\underline{\text { mclabbate@iado-conicet.gob.ar }}$

\begin{abstract}
:
Planktonic ciliates constitute a fundamental component among microzooplankton and play a prominent role in carbon transport at the base of marine food webs. How these organisms respond to shifting environmental regimes is unclear and constitutes a current challenge under global ocean changes. Here we examine a multiannual field survey covering 25 years in the Bahía Blanca Estuary (Argentina), a shallow, flood-plain system dominated by wind and tidal energy. We found that the estuary experienced marked changes in wind dominant regimes and an increase in water turbidity driven from the joint effect of persistent long-fetch winds and the indirect effect of the Southern Annular Mode. Along with these changes, we found that zooplankton components, i.e. ciliates and the dominant estuarine copepod Acartia tonsa, showed a negative trend during the period 1986-2011. We showed that the combined effects of wind and turbidity with other environmental variables (chlorophyll, salinity and nutrients) consistently explained the variability of observed shifts. Tintinnids were more vulnerable to wind patterns and turbidity while showed a loss of synchrony with primary productivity. Water turbidity produced a dome-like pattern on tintinnids, oligotrichs and A. tonsa, implying that the highest abundance of organisms occurred under moderate values ( 50 NTU) of turbidity. In contrast, the response to wind patterns was not generalizable probably owing to species-specific traits. Observed trends denote that wind-induced processes in shallow ecosystems with internal sources of suspended sediments, are essential on ciliate dynamics and that such effects can propagate trough the interannual variability of copepods.
\end{abstract}




\section{Highlights}

- Planktonic ciliate's abundance decreased over the last 25 years in a shallow estuary. Decreasing cell abundance was linked to changes in wind dominant regimes and increased water turbidity. Tintinnids were more vulnerable to wind patterns and turbidity and lost synchrony with primary productivity. Interannual variability of the copepod Acartia tonsa followed the changes in ciliate community. Erosive processes in shallow estuaries impact on the interannual dynamics of ciliates and such effects can cascade-up to copepods.

Keywords : Tintinnids, Oligotrichs, Acartia tonsa, Wind, Turbidity, Estuaries 


\section{Introduction}

In coastal ecosystems, tintinnids and oligotrichs (hereafter collectively referred to as 'ciliates'), constitute a fundamental component among microzooplankton and play a prominent role in carbon transport at the base of marine food webs (Keller and Hood 2011, Mitra et al. 2014, Legendre and Rivkin 2015). They rapidly synchronize productivity patterns due to their short generation time and graze an average of $60 \%$ of daily primary production and $10 \%$ of daily bacterial production (Steinberg and Landry 2017), while representing nearly $30 \%$ of copepods diet (Calbet and Saiz 2005). In spite of their relevance in both trophic dynamics and carbon fluxes, ciliate's responses to environmental drivers remain elusive due to the lack of sustained long-term surveys and synoptic approaches (Clamp and Lynn 2017). Empirical evidence has shown a prominent role of temperature and food on ciliate's dynamics, however, the long-term response of these organisms is shaped by a variety of additional drivers (Dolan and Gallegos 2001, Aberle et al. 2013, López-Abbate et al. 2015). Hence, we urgently need sustained field observations that integrate ecological responses of natural communities to multi-scale drivers (Heger et al. 2014). Sustained observations of wide-varying environments are critical to understand underlying mechanisms shaping the structure and function of plankton communities (Boyd and Hutchins 2012) and to detect non-linearities (Kreyling et al. 2018). This information will ultimately facilitate the anticipation of inefficient carbon transfer toward higher trophic levels (Wohlers et al. 2009).

Among shallow estuaries, surface winds have an important influence on the seasonal pattern of plankton (Reynolds 2006). This influence is driven by physical processes such as waves, currents, microscale turbulence and particles resuspension (Scully et al. 2005, Li and Li 2011, Whipple et al. 2018). Microscale turbulence induced by surface winds, for 
instance, reduces the sinking velocity of suspended organisms and can enhance prey capture and nutrient uptake (Kiørboe and Saiz 1995, Barton et al. 2014, Pécseli et al. 2014). In addition, the transport of inorganic nutrients toward illuminated layers produced by wind-driven water mixing, regulates phytoplankton growth and availability (Kiørboe 2008). In flood-plain estuaries, wind-induced currents and wind waves are among the most important factors that favour sediment resuspension in the water column, and profoundly interfere with the light penetration (Weir and McManus 1987, Brand et al. 2010, Bever et al. 2018). A high concentration of suspended particles, in turn, can restrict ciliate reproduction (Jack and Gilbert 1993), while handling-limited predation by the interference of inedible suspensoids with prey uptake has been observed in planktonic filter feeders such as cladocerans (Laspoumaderes et al. 2017).

Located in the SW Atlantic Ocean, the Bahía Blanca Estuary is a shallow, flood-plain estuary dominated by wind and tidal energy (Piccolo and Perillo 1990). In the last decades, the region has experienced climate-driven environmental changes encompassing warmer winters and extreme dry periods (Aravena and Luckman 2009, Guinder et al. 2010), along with persistent positive anomalies of the Southern Annular Mode (SAM). Such anomalies are associated with stronger than normal westerlies over the mid-high-latitudes and weaker westerlies in the mid-latitudes (Marshall 2003). Concurrently, water turbidity has shown a positive trend in the last 15 years, presumably as a response to wind shifts and the lateral erosion of salt marshes associated with sea level rise (Pratolongo et al. 2013, López-Abbate et al. 2017). Modelling approaches revealed the emergence of both, wind speed and water turbidity, as dominant factors driving the decline of chlorophyll concentration in recent years (López-Abbate et al. 2017), however, the interannual response of phagotrophic plankton has been so far overlooked. Ciliates contribute with the highest carbon biomass 
within estuarine microzooplankton during the entire annual cycle. Experimental approaches have revealed that these organisms are the preferred food source of the dominant copepod Acartia tonsa (Diodato and Hoffmeyer 2008). This omnivorous species cohabits with ciliates during most of the year whereas it may reach up to $90 \%$ of total mesozooplankton abundance during the warm season, concurrent with the highest annual concentration of tintinnids (Hoffmeyer 2004). In turn, A. tonsa is one of the main food sources of planktivorous fish (López Cazorla et al. 2011). The aim of this study is to quantify the interannual response of ciliates to environment drivers, with emphasis on wind patterns and water turbidity. For this purpose, we have employed a unique multiannual data set in the SW Atlantic Ocean that covered the abundance of micro- (ciliates community) and mesozooplankton (A. tonsa) along with an exhaustive environmental data set. To quantify the effect of multiple drivers on ciliates and A. tonsa, we used Boosted Regression Trees (BRT). The analyses are organized in the following steps: 1) exploration of top-down and bottom-up interactions, 2) testing of the hypothetical cause-effect models, 3) identification of dominant drivers according to the amount of explained deviance and 4) comparison of the partial response of zooplankton groups to wind patterns and water turbidity.

\section{Materials and Methods}

\section{Study area}

The Bahía Blanca Estuary $\left(38^{\circ} 42^{\prime}-39^{\circ} 25^{\prime} \mathrm{S}, 61^{\circ} 50^{\prime}-62^{\circ} 22^{\prime} \mathrm{W}\right)$ is located in a temperate, semiarid region at the northern boundary of Patagonia in the SW Atlantic coast, Argentina. Mesotidal setting and wind-driven mixing prevents stratification during most of the year (Perillo et al. 2001). The depth of the estuary ranges between 1 and $24 \mathrm{~m}$, while the mean 
value is about $10 \mathrm{~m}$ (Perillo et al. 2001). Half of the estuarine basin consists of extensive low-slope tidal flats densely fragmented by tidal courses (Perillo 2009) oriented NW-SE (Fig. 1). The feature promotes an intense interaction between the water column and the bottom layers, whose first 3-4 $\mathrm{m}$ are composed by a massive deposit of unstructured mud (Pratolongo et al. 2017). Predominant NW winds run parallel to the estuarine main channels and produce high energy wind waves that enhances the erosion of tidal flats (Perillo and Sequeira 1989, Pratolongo et al. 2010). Grain size in the lower mudflats are in the very coarse to fine silt range (mode of $32 \mu \mathrm{m}$ ), while suspended sediments size in the water column varies between 1 and $50 \mu \mathrm{m}$ (mode of $10 \mu \mathrm{m}$ ) (Guinder et al. 2015, Zapperi et al. 2017).

The main estuarine channel is periodically dredged since 1958, while the harbour basin in the inner reach is water-jettied to prevent sediment deposition. The dredged volume increased 11-fold after 1999 due to the deepening and widening of the access channel. Currently, dredging operations are executed along an area of $20 \mathrm{~km}$ long and $190 \mathrm{~m}$ width and attain a regular depth of $13.5 \mathrm{~m}$ (López-Abbate et al. 2017). As a result, the volume of sediment extraction by dredging significantly increased from a yearly mean of $240,714 \mathrm{~m}^{3}$ in $1958-1998$, to $2,657,919 \mathrm{~m}^{3}$ in $1999-2011$. In addition, the development of urban centres fostered point-source nutrient loading, which can sporadically exceed the tolerance of microzooplankton due to the toxic effect of ammonium (López-Abbate et al. 2015).

\section{Biological data}

Microzooplankton samples were taken from the surface layer using a van Dorn Bottle (2.5

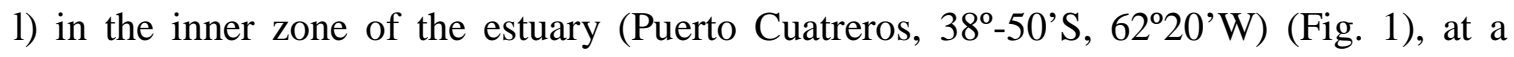
monthly frequency during discontinuous periods from 1986 to 2011. The quantification of 
ciliates was done by settling a variable volume (10-50 ml, depending on sediment and plankton concentration) of preserved seawater sample (neutral Lugol's iodine, f.c. $10 \%$ ) in Utermöhl chambers during $24 \mathrm{~h}$. The entire chamber was analysed under a Wild M20 inverted microscope (Hasle 1978). We here focused on tintinnids and oligotrichs since they represent the most abundant groups within microzooplankton in the Bahía Blanca Estuary (Pettigrosso 2003, Barría de Cao et al. 2005). A total of 178 samples were analysed for the quantification of tintinnids, while 97 samples were analysed for the quantification of oligotrichs. Samples for tintinnids quantification were taken at a monthly or biweekly frequency during the following periods: April 1986 to May 1989, June 1995 to April 1997, March 2002 to March 2004, October 2006 to February 2008 and July 2008 to April 2011. Samples for oligotrichs quantification were also taken at a monthly or biweekly frequency during the following periods: February 1994 to February 1995, January 2007 to February 2008, July 2008 to April 2011. Tintinnids were identified to the species level, while oligotrichs were in some cases identified to the genus level while in other cases they were counted as a whole. From 1978 to 2009, samples for chlorophyll $a$ analysis were taken uninterruptedly at the same location, on a fortnightly basis. Chlorophyll $a$ concentration was quantified by the extraction with acetone $(90 \%)$ at a controlled room temperature and then refrigerated in the dark at $4{ }^{\circ} \mathrm{C}$ for $24 \mathrm{~h}$. Then the samples were centrifuged and the supernatant separated. The pigment concentration was determined by spectrophotometry (Jenway 6715 UV-Vis) using the equations of Lorenzen (1967). To assess predator-prey links we also included data on the dominant copepod species, A. tonsa, which is a key component of the estuarine food web. Adults of A. tonsa were obtained from mesozooplankton samples collected at a monthly frequency during the following periods: July 1979 to August 1980, August 1982 to September 1983, July 1990 to August 1991, 
April 2002 to November 2002, January 2007 to February 2008, July 2008 to December 2010 and January 2015 to December 2015. Samples were collected with subsurface horizontal tows using a $200 \mu \mathrm{m}$ mesh plankton net and $0.30 \mathrm{~m}$ mouth diameter equipped with a Hydrobios flowmeter and towed for $10 \mathrm{~min}$ at a constant speed of 2 knots. Surface sampling bias was minimized by reproducing the sampling protocol and the subsequent sample treatment throughout the studied period. Samples were fixed ( $4 \%$ formalin) and analysed under a Wild M5 stereoscopic microscope using a Bogorov chamber following the methodology proposed by Boltovskoy (1981).

\section{Environmental data}

Water temperature $\left({ }^{\circ} \mathrm{C}\right)$, salinity and turbidity (NTU) were measured simultaneous to biological sampling using a digital multi-sensor Horiba U-10. Likewise, samples for the determination of dissolved inorganic nutrients were taken from the surface layer using a van Dorn Bottle $(2.5$ l) at a monthly frequency. Nitrate, nitrite, phosphate and silicate concentrations were determined following the methods described in Spetter et al. (2015). The sum of nitrate and nitrite was expressed as the concentration of dissolved inorganic nitrogen (DIN). Data on wind speed and direction were provided by the National Weather Service (http://www.smn.gov.ar). Hourly data were available for the period 1991-2015 while previous to 1991 (1978-1990) data were recorded every three hours.

The region is influenced by large-scale atmospheric phenomena such as SAM and El Niño Southern Oscillation (ENSO) (Vera et al. 2004, Menéndez and Carril 2010). The SAMMarshall index, based on the difference of mean sea level pressure between the latitudes $40^{\circ} \mathrm{S}$ and $65^{\circ} \mathrm{S}$, was selected for the analysis as it reduces the influence of spurious trends of reanalysis products (Marshall 2003). The temporal evolution of ENSO was assessed by 
the SST averaged anomaly in the Niño 3.4 region (Niño 3.4 index) in the central-east region of the Tropical Pacific Ocean $\left(5^{\circ} \mathrm{N}-5^{\circ} \mathrm{S}, 170^{\circ}-120^{\circ} \mathrm{W}\right)$ (Trenberth 1997). The atmospheric variables used to assess indirect effect of climate modes on wind patterns were air temperature and sea level pressure. Monthly record covered the northern SW Atlantic coast including the estuarine area and extending from -35.0 to $-42.5^{\circ} \mathrm{N}$ and from 295.0 to $302.5^{\circ} \mathrm{E}$. Regional atmospheric variables as well as the standardized modes of atmospheric variability were obtained from the Climate Diagnostics Center (NCEP/NCAR) reanalysis fields.

\section{Data analysis}

Identification of trends in biological data

Owing to the different frequency and time-coverage of time series, all records were screened and averaged to obtain monthly values prior the analysis. To evaluate the influence of co-occurring environmental drivers on the interannual response of ciliates and the copepod A. tonsa, we first analysed the general trend of tintinnids and oligotrichs abundance by fitting a linear model on monthly records as a function of time. The longterm variability of log-transformed abundance of the three zooplankton groups and wind speed were also fitted to linear models to compute the yearly rate of change. In addition, the long-term trend of individual tintinnid's species was displayed in a heat map using the annual mean of log-transformed abundance. The phenology of tintinnids, whose sampling frequency allowed a more detailed examination, was evaluated using Generalized Additive Model (GAM). For this purpose, we compared the annual cycle using mean monthly records as a function of time (months) during two periods: 1986-2002 and 2003-2011. These periods were selected considering the significant breakpoint on the chlorophyll $a$ 
time series noticed in 2002 (López-Abbate et al. 2017) and assuming a bottom-up linkage between tintinnids and chlorophyll.

Interconnection between climate modes, regional atmospheric variability and water turbidity

Wind patterns along the period 1991-2015 were visualized through annual wind roses with the R-function plot.windrose ( $\mathrm{R}$ Development Core Team 2014). Hourly data were employed to plot the frequency of wind speed and direction by year. Records previous to 1991 were not plotted due to lower than hourly data frequency. The percentage of 'calms', defined as the fraction of zero wind speed along the year, was calculated by the windRose function from the R-package openair. To improve the visualization of long-term trends, annual means of wind speed, wind direction and water turbidity were fitted as a function of time by a GAM. Yearly records in the period 1978-2015 were fitted with a logit link function using the R-package mgcv.

To explore correlations between water turbidity and wind patterns with climate variables of interest operating at regional and global scales, we constructed a path model (SEM). We first constructed the theoretical model by ranking the explanatory variables, from global (ENSO, SAM), regional (air temperature and sea level pressure) and local scale variables (precipitation, wind speed, wind direction and SST), to the response variable (water turbidity), thus assuming causal relationships. ENSO and SAM signals are known to covary during austral summer (Fogt et al. 2011), therefore they were set as covariates in the model. Path coefficients were determined by simple and partial multivariate regression and Monte Carlo permutation tests (1000 replicates), while the Chi-square values were used to 
assess the robustness of models (Alsterberg et al. 2013). Path analysis was performed using the R-package lavaan.

\section{Influence of environmental drivers on plankton groups}

Once defined the long-term modifications on ciliate community, we identified the environmental variables driving such changes by means of Regression Tree Models. Regression Trees are non-linear predictive models that can be used when data have lots of features which interact in nonlinear ways. The method is based on the partition of the predictor space into rectangles until data fragments can fit simple models. Predictors and split points are chosen to minimize prediction errors, which is calculated as the sum of squared errors between the predicted values and the actual values (Breiman et al. 1984, De'ath and Fabricius 2000). We here used Boosted Regression Tree (BRT) which combines simple models (trees) to gain predictive power (Elith et al. 2008). The number of times a predictor is selected for splitting and the amount of explained deviance, allow to rank predictive variables according to their relative importance. The R-packages gbm and dismo were employed for the construction of BRT. Models were trained by setting the logtransformed abundance of tintinnids and oligotrichs as the response variables, and chlorophyll $a$ concentration, wind speed, wind direction, salinity, turbidity and dissolved inorganic nutrient concentration (DIN, phosphate and silicate) as the explanatory variables. Given the positive correlation between ciliates and chlorophyll $a$ concentration with the abundance of A. tonsa (Diodato and Hoffmeyer 2008), we assumed that the ecological interaction among groups was dominated by the bottom-up control exerted upon the copepod. Thus we constructed an additional model using the abundance of $A$. tonsa as the response variable and the concentration of ciliates and chlorophyll $a$, wind speed, wind 
direction, salinity and turbidity as the explanatory variables. The lack of data regarding the loss of A. tonsa by fish predation, as well as other unobservable factors, can significantly reduce the predictive power of models. In BRT, pre-selection of variable is not required since the model largely ignores non-informative predictors when fitting trees (Elith et al. 2008). Sea surface temperature (SST), nevertheless, was not included to avoid spurious upweighting due to autocorrelation. The marked seasonality of ciliates and A. tonsa, may further contribute to the up-weighting of SST in BRT models. Model fitting was evaluated by the cross-validation deviance and standard error. Given that wind speed, wind direction and turbidity explained more than $29 \%$ of variance when predicting the abundance of zooplankton groups, we examined the partial response of tintinnids, oligotrichs and $A$. tonsa to these three predictors.

\section{Results}

Long-term dynamics of ciliates

The mean monthly abundance of tintinnids along the time series was 3416 cell $^{-1}$ (Table S1), while the monthly abundance of oligotrichs was lower and averaged 1403 cell $^{-1}$ (Table S2). The assessment of the long-term variation of ciliates showed a negative interannual trend (Fig. 2). Tintinnids declined at a yearly rate of $2.8 \%\left(\mathrm{p}<0.001, \mathrm{R}^{2}=\right.$

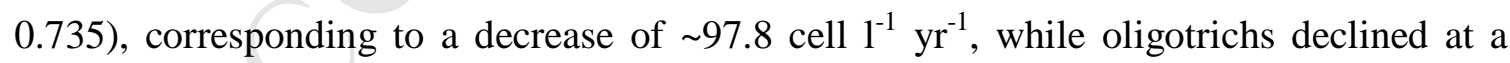
yearly rate of $1.6 \%$, although the trend was not significant $\left(\mathrm{p}=0.221, \mathrm{R}^{2}=0.281\right)$. Likewise, the abundance of the copepod A. tonsa also showed a negative trend $\left(\mathrm{p}=0.005, \mathrm{R}^{2}=0.605\right)$ and a yearly rate of decline of $3.3 \%$. A total of 11 tintinnid species showed a negative trend, including the dominant species Tintinnidium balechi, while Tintinnopsis brasiliensis and T. sp. showed a positive trend, and Metacylis aff. mereschkowskyi, T. buetschlii, T. 
buetschlii var. mortensenii, Favella taraikaensis Leprotintinnus pellucidus and T. amphora showed only occasional occurrence (Table S1, Fig. 3). The most abundant species within ciliates throughout the time series was T. balechi, which represented an average of $27 \%$ of total abundance and revealed a steeper rate of decline $\left(4.3 \%, \mathrm{p}=0.008, \mathrm{R}^{2}=0.425\right.$, data not shown) compared with total tintinnid abundance. The percentage decline represented a decrease of 52.4 ind $1^{-1} \mathrm{yr}^{-1}$. The annual cycle of tintinnids before and after 2003 revealed the loss of the spring pulse that followed the winter phytoplankton bloom in recent years (Fig. 4).

\section{Trends in environmental conditions}

Wind speed showed a slowdown rate of $0.4 \mathrm{~m} \mathrm{~s}^{-1} \mathrm{y}^{-1}$ since 1998 to date (linear regression model: $\mathrm{p}<0.001, \mathrm{R}^{2}=0.680$ ), which represents a decline of $32.7 \%$ (Fig. 5, Fig. 6a). During the period 1986-2002, wind speed averaged $6.51 \mathrm{~m} \mathrm{~s}^{-1}$ while the mean annual wind speed in the following period (2003-2015) was $5.71 \mathrm{~m} \mathrm{~s}^{-1}$. Mean annual wind direction showed higher persistence toward of NW quadrant since the 1978 to date (linear regression model: $\mathrm{p}<0.001, \mathrm{R}^{2}=0.480$ ) (Fig. 5, Fig. 6a). In addition, the percentage of calm periods declined at a yearly rate of $2 \%$ since the beginning of the time series (linear regression model: $\mathrm{p}<0.001, \mathrm{R}^{2}=0.509$ ). Water turbidity increased accordingly after 1999 (Fig. 6a) at a yearly rate of $4 \%\left(p<0.001, \mathrm{R}^{2}=0.745\right)$, while SEM revealed that in the period 1978-2011, it responded to the direct effect of wind speed, wind direction and SST and to the indirect effect of SAM and ENSO $\left(X^{2}=450.49, \mathrm{df}=12, \mathrm{p}<0.001\right.$, Fig. $\left.6 \mathrm{~b}\right)$. Mean annual SST and salinity was $15.7^{\circ} \mathrm{C}$ and 33.2 respectively, and both variables evidenced no linear trends along the time series. Positive trends were observed in the mean annual concentration of DIN ( $\left.p=0.002, R^{2}=0.290\right)$ and phosphate $\left(p<0.001, R^{2}=0.470\right)$, while no evident trend was 
observed in the concentration of silicate. Mean annual concentration of DIN, phosphate and silicate was $6.90,2.07$ and $90.37 \mu \mathrm{M}$ respectively, while the yearly rate of DIN and phosphate increase was 1.1 and $0.8 \%$ respectively.

\section{Environmental drivers of ciliates and A. tonsa abundance}

BRT yielded evidence of the response of tintinnids $\left(R^{2}=0.528\right)$, oligotrichs $\left(R^{2}=0.982\right)$ and A. tonsa $\left(\mathrm{R}^{2}=0.435\right)$ to environmental variables. The ranking of driver importance (Fig. 7$)$ revealed that the optimal predictors of tintinnid abundance were turbidity, wind speed, wind direction and DIN, which explained 25.9, 22.3, 14.0 and $13.1 \%$ of total tintinnids variability, respectively. Predictors that better explained the variability of oligotrichs were phosphate (34\%), silicate (26.5\%), wind speed (25.1\%) and turbidity (12.2\%), while the variability of $A$. tonsa was mostly predicted by tintinnid abundance (27.0\%), salinity (18.7 $\%)$, turbidity $(12.2 \%)$ and wind direction $(11.7 \%)$. Taken together, wind speed, wind direction and turbidity explained $62.2,39.4$ and $29.8 \%$ of tintinnids, oligotrichs and $A$. tonsa variability, respectively. Partial dependence plots (Fig. 8) revealed that tintinnids and A. tonsa adults showed a saturating relationship with wind speed, with a threshold value near $25 \mathrm{~m} \mathrm{~s}^{-1}$. Similarly, tintinnids and $A$. tonsa adults showed a binomial-like relationship with winds direction, i.e., the highest abundance values occurred in concurrence with winds coming from the SE quadrant and lowest abundance values in concurrence with winds coming from the NW quadrant. A dome-like pattern to water turbidity was register in all zooplankton groups, with the highest abundance values occurring at nearly 50 NTU.

\section{Discussion}




\section{Ciliates and A. tonsa interannual response}

During the studied period (1986-2009), we identified a progressive decline of tintinnids and A. tonsa adults and a less obvious decline on oligotrichs concentration. Parallel to the negative trend of zooplankton groups, phytoplankton community showed a drastic erosion of seasonal peaks and a shift from the typical unimodal productivity pattern to a bimodal regime (López-Abbate et al. 2017). Along the time series, two tintinnids species, Tintinnopsis brasiliensis and T. sp., showed a positive trend. The oral diameter of these species ranges from 56 to $90 \mu \mathrm{m}$, which is above the mean oral diameter of the estuarine tintinnids (mean $<40 \mu \mathrm{m}$ ). The oral area is proportional to prey encounter rate, and a wider encounter radius may confer a competitive advantage against species with narrower oral area constrained to a smaller prey size spectrum (Dolan 2010). The loss of the winter phytoplankton bloom in the last three decades, produced a loss of synchrony between tintinnids and primary producers, and changed the seasonal pattern of resource availability for higher trophic levels. In turn, the abundance of the dominant copepod A. tonsa, showed a significant positive relationship with tintinnids, denoting that the ecological interaction among groups was dominated by the bottom-up control exerted upon the copepod. In addition, the type of interaction confirmed by our model, allows to confidently attribute the negative trend of tintinnids to environmental factors. Tintinnids are a relevant prey item among estuarine copepod's diet (Dolan and Gallegos 2001), and during warm months in the Bahía Blanca Estuary, tintinnids represent nearly $78 \%$ of total particles filtration by the copepod A. tonsa (Diodato and Hoffmeyer 2008). Our results revealed that environmental factors produced cascade-up effects, from phytoplankton to copepods, and imply a high probability that such effects resonate into the dynamics of planktivorous fish that prey on $A$. tonsa (López Cazorla et al. 2011). The disclosure of long-term patterns further highlights 
the importance of sustained ocean observation systems to discriminate directional trends on ciliates and to identify clues regarding the loss of functional diversity.

\section{Long-term patterns of wind and water turbidity}

Regional wind patterns evidenced a shift toward low intensity but highly persistent NW winds in the last 25 years. Local winds over the South Atlantic are modulated by the intensity and displacement of the South Atlantic subtropical anticyclone (Venegas et al. 1996, Palma et al. 2004). In the last decades, this anticyclone revealed a slight southward movement (Dragani et al. 2010) and caused wind pattern modifications over the region (Simionato et al. 2005, Brendel et al. 2017). At the interannual time scale, the southward displacement of the anticyclone tends to be associated with positive phases of SAM (Sun et al. 2017). Such large scale atmospheric variability was superimposed with the variability of local winds as suggested by our SEM model, in which both wind speed and wind direction showed teleconnections with SAM through the effect of sea level pressure anomalies. At longer timescales, the non-annular component of SAM produces contrasting spatial responses on SST and could also influence local wind patterns (Yeo and Kim 2015). In fact, a noticeable inflection in both wind speed and direction was perceived around 1999 (Fig. 6a), in concurrence with the decadal shift on SAM spatial structure.

Although the increase of water turbidity is generally attributed to an increase in wind speed (Bever et al. 2018), in geomorphologically complex systems, other attributes such as the prevailing wind direction also come into play. The prominent role of wind direction on water turbidity revealed by the data, can be interpreted as the potential of winds cardinally aligned with the estuarine main channels to produce longer fetch and high energy wind waves (Perillo and Sequeira 1989, Pratolongo et al. 2010). High energy wind waves boost 
the lateral erosion of wide expansions of tidal flats and promote the mobilization of soft sediments to the water column thereby contributing to increase water turbidity (Piccolo et al. 2008). Among estuaries with strong interaction across coastal forms (i.e. saltmarshes and flood-plains) and the water column, wind attributes capable of producing wind waves are thereby better descriptors of water turbidity than wind velocity alone (Cho 2007, Reisinger et al. 2017). The simultaneous intensification of bottom shear stress due to the expansion of the dredged area may additionally amplify the effect of changing wind patterns on water turbidity (López-Abbate et al. 2017).

The significant positive effect of SST on turbidity denotes the recurrent seasonal pattern of this variable, which typically shows maximum values during the warm months. This seasonal pattern is echoed by the dynamics of the borrowing crab, Neohelice granulata, which produces an intense sediment destabilization within tidal flats and a conspicuous mobilization of soft sediments toward the water column during summer (Zapperi et al. 2016). The present rate of sea level transgression into the estuarine basin may also affect the positive trend of water turbidity (Lanfredi et al. 1988). Sea level rise presently causes an intense lateral erosion of saltmarshes which already experienced a $33 \%$ loss of its area since 1967 (Pratolongo et al. 2013). Marsh boundary erosion along with the $50 \%$ loss of shrub-like steeps area due to the settlement of human infrastructure (Pratolongo et al. 2013), likely stimulated the continuous transport of mud deposits to the adjacent water column.

\section{Partial response of zooplankton groups to wind patterns and water turbidity}

Long-term evaluation of environmental and biotic data revealed a prominent role of wind and water turbidity as underlying drivers of the decline of zooplankton groups, especially 
tintinnids. In turn, the consistent increase on water turbidity resulted from the joint effect of wind patterns and the indirect effect of SAM in the last two decades. Further external forces may improve the consistency of predictive models constructed here. For instance, behavioural retention, migration and horizontal advection, are important factors that drive the spatial distribution of ciliates and their assessment requires a detailed three-dimensional observation of biota.

Partial dependence plots, denoted that wind speed produced a logistic-like pattern in the concentration of tintinnids and A. tonsa, while oligotrichs evidenced a dome-like pattern. Wind mixing is one of the most important drivers that determines three-dimensional distribution of plankton in shallow environments (Moreno-Ostos et al. 2008, Cardoso and Motta Marques 2009, Zhou et al. 2015). Additionally, wind-driven water turbulence may enhance or reduce prey encounter depending on the size of organisms, sensory strategies and behavioural traits (Pécseli et al. 2014). Ambush feeders such as A. tonsa when offered motile prey, are more dependent on turbulence to effectively encounter prey than motionless predators, while suspension feeders that create feeding currents, such as most ciliates, are less dependent on turbulence (Kiørboe and Saiz 1995). However, turbulence also affects ciliate's growth and sinking rate and their response is thereby less generalizable (Martínez et al. 2017). Fast-sinking tintinnids with agglomerated lorica, would be more dependent on wind-induced turbulence than slower sinking oligotrichs to retain suspended populations. The broad majority of the tintinnid species found in the estuary display agglutinated minerals, mostly sediments, covering the surface of their lorica, and this particular trait could underlie the specific response of both tintinnids and oligotrichs to wind speed. 
Tintinnids and A. tonsa showed the strongest dependence on wind direction and evidenced a negative relationship with winds coming from the NW quadrant. In the Bahía Blanca Estuary, NW winds are effective impellers of erosive wind waves, and water turbidity can thereby be described as a function of wind direction (Piccolo et al. 2008). Accordingly, the response of plankton to wind direction is likely mediated by water turbidity, although wind direction may also affect the vertical distribution and retention of organisms. Wind-induced internal waves, for instance, reduce the likelihood of sedimentation losses (Hingsamer et al. 2014). Waves generated by NW winds across the estuary have relatively small wavelengths implying that the turnover due to waves only occurs in the upper 2-3 m (Perillo and Sequeira 1989). The confinement of turbulence mixing within the upper layers likely intensifies the sedimentation of rapidly sinking plankton such as tintinnids. Our models, however, are based on the abundance of organisms at the surface layer, and do not provide evidence on the sedimentation of organisms or the compensatory dynamics such as vertical migration. NW winds are further directed toward the mouth of the estuary and can intensify the ebb-oriented transport of suspensoids toward the shelf area. Outflowing winds are known to produce the horizontal advection of plankton and the local exclusion of cells (Wolfe et al. 2015), and may be an additional factor driving the negative trend of tintinnids and $A$. tonsa to NW winds.

Water turbidity produced a dome-like pattern in zooplankton groups denoting that the highest abundance values occur under moderate levels of turbidity. Increased concentration of suspended sediments in the size range of zooplankton prey, limits prey encounter rate and handling (Boenigk and Novarino 2004). In fact, experimental data revealed that water turbidity reduced the growth and survival of heterotrophic nanoflagellates owing to the interference of mineral suspensoids with the uptake of prey rather than to the physical 
damage of cells (Sommaruga and Kandolf 2014). In particular, the mean oral diameter of the 20 tintinnid species reported in the Bahía Blanca Estuary was $41 \mu \mathrm{m}$, suggesting that the size spectrum of prey are below 10-15 $\mu \mathrm{m}$ (Dolan et al. 2012). The prey size spectrum of tintinnids fall well between the size range of suspended sediments in the Bahía Blanca Estuary, which varies between 1-50 $\mu \mathrm{m}$ while the modal value is $10 \mu \mathrm{m}$ (Guinder et al. 2015). Above $50 \mathrm{NTU}$, water turbidity produced a negative effect on zooplankton groups, denoting that this factor may be considered as an ecological disturbance. Maximum zooplankton biomass, however, occurred at intermediate values of water turbidity, revealing that tintinnids, oligotrichs and $A$. tons $a$ are able to successfully coexist under this scenario. Optimal coexistence of functional groups at the average scale gradient of disturbance (i.e. water turbidity), partly supports the Intermediate Disturbance Hypothesis, which states that species diversity is maximized when disturbance intervals are intermediate (Connell 1978). Optimal disturbance interval depends on the generation time of the exposed organisms (Gaedeke and Sommer 1986), which in this case ranges between days to hours, and coincides with the time-lag needed to wind and tides to produce observable shifts in water turbidity (Perillo 1995).

At the long temporal scale, water turbidity may have produced a detrimental effect on ciliates by reducing the ratio between inedible suspensoids and phytoplankton, and forcing ciliates to an additional energy expenditure to sort inedible particles. Mixotrophic oligotrichs, however, are less sensitive to water turbidity and likely constitute the trophic link between bacteria and higher trophic levels due to the exclusion of light limited phytoplankton and filter feeders (Sommaruga and Kandolf 2014, Kammerlander et al. 2016). The close link between oligotrichs and inorganic nutrients revealed by BRT denotes that higher inorganic nutrient concentration in the last years may have mitigated the low 
concentration of prey availability. Wind-induced processes can thereby influence the food web organization by changing the spatial distribution of plankton and the ratio between edible and inedible particles.

Human activities at coastal areas are restricting the ability of coastal wetlands to compensate the effect of climate change, and projection based on the IPCC mean sea level rise scenario revealed that $20 \%$ of salt-marsh area will be lost by 2100 (Craft et al. 2009). The cumulative effect of sea level rise along with intense land use and limited ecosystem feedbacks, will enhance the erosion of coastal margins and the mobilization of soft sentiments toward the adjacent water column (Kirwan and Megonigal 2013). Shallow ecosystems with internal sources of suspended sediments, are thereby highly vulnerable to erosive processes. Our results provide quantitative evidence on the long-term response of pelagic ciliates to growing water turbidity and further revealed that ciliates can propagate such effects trough the interannual variability of copepods.

\section{Acknowledgment}

We thank Raúl Asteasuain and the staff from the IADO's Marine Chemistry Lab for the collection and analysis of samples. We are also grateful to Walter Melo for providing the study map. This study was supported by the National Agency for Promotion of Science and Technology (ANPCyT) (PIP D-738/2010) the National Scientific and Technical Research Council (CONICET) and by the Instituto Argentino de Oceanografía, (CONICET-UNS).

\section{Figure and table captions}

Figure 1. Map of the Bahía Blanca Estuary, SW Atlantic Ocean, showing the location of the sampling site at the inner estuary close to "Puerto Cuatreros". Main tributaries, sewer 
497

498

499

500

501

502

503

504

505

506

507

508

509

510

511

512

513

discharge points, industrial and port areas (grey area) and the main urban centers (orange area) are also shown. Dredging operations take place periodically in the port area and in the Principal Channel.

Figure 2. Long-term changes of tintinnids, oligotrichs (cell $1^{-1}$, upper and mid panels, respectively) and Acartia tonsa (ind $\mathrm{m}^{-3}$, lower panel) abundance. Significant trends are indicated by a linear fit and confidence interval at $95 \% . \mathrm{R}^{2}$ and $\mathrm{p}$-values are indicated inside the plots.

Figure 3. Mean annual log-transformed abundance $\left(\right.$ cell $\left.1^{-1}\right)$ of tintinnid species over the time series. Years with incomplete monthly observations (1986-1989, 1996-1997 and 20042006) were averaged together. Negative trend was observed in almost all species except for Tintinnopsis brasiliensis and T. sp. that showed a positive trend. Scale bar denotes the value of tintinnid abundance.

Figure 4. GAM estimates of mean monthly log-transformed abundance (cell $1^{-1}$ ) of tintinnids in the periods 1986-2002 (blue dots) and 2003-2011 (red dots) denoting the loss of the spring peak following the winter phytoplankton bloom in recent years. $\mathrm{R}^{2}$ and $\mathrm{p}$ values are indicated inside the plots.

Figure 5. Annual wind roses in the period 1991-2015 showing the frequency of wind speed and direction (\%). Plots denotes the decreased prevalence of wind coming from the NE, SE and SW quadrants. Mean wind velocity decreased after 2000 and the relative persistence of 
517

518

519

520

521

522

523

524

525

526

527

528

529

530

531

532

533

534

535

536

537

538

539

NW winds intensified over the time series. Scale bar at the right side of the plots denotes wind speed (ws).

Figure 6. a) Annual mean of wind speed (upper panel), wind direction (mid panel) and turbidity (lower panel) in the Bahía Blanca Estuary over the period 1978-2011. b) Path diagrams showing significant $(\mathrm{p}<0.05)$ interconnections between climate and environmental drivers and water turbidity. At each significant path the positive (blue) and negative (red) effects are represented by the standardized coefficients. The variables used in SEM were: SAM-Marshall index (SAM), Niño 3.4 index (N3.4), seal level pressure (SLP), air temperature (Air Temp), precipitation (PP), wind speed (ws), wind direction (wd), sea surface temperature (SST) and turbidity (turb).

Figure 7. The ranking of explanatory variable importance driving the response of tintinnids (left panel) and oligotrichs (right panel) abundance. The variables used in the BRT model were wind speed (ws), wind direction (wd), turbidity (turb), chlorophyll concentration (chla), salinity (sal), dissolved inorganic nitrogen (DIN), phosphate (P) and silicate ( $\mathrm{Si}$ ). $\mathrm{R}^{2}$ values are indicated inside the plots.

Figure 8. Partial dependence plots for wind speed (ws), wind direction (wd) and turbidity as depicted by BRT of zooplankton groups: a) tintinnids, b) oligotrichs and c) Acartia tonsa. Percentage of explained variance of each predictor is shown between parentheses.

\section{References}


Aberle, N., K. G. Schulz, A. Stuhr, A. M. Malzahn, A. Ludwig, and U. Riebesell. 2013. High tolerance of microzooplankton to ocean acidification in an Arctic coastal plankton community. Biogeosciences 10:1471-1481.

Alsterberg, C., J. S. Eklöf, L. Gamfeldt, J. N. Havenhand, and K. Sundbäck. 2013. Consumers mediate the effects of experimental ocean acidification and warming on primary producers. Proceedings of the National Academy of Sciences:201303797.

Aravena, J. C. and B. H. Luckman. 2009. Spatio $\square$ temporal rainfall patterns in Southern South America. International Journal of Climatology 29:2106-2120.

Barría de Cao, M. S., D. Beigt, and C. Piccolo. 2005. Temporal variability of diversity and biomass of tintinnids (Ciliophora) in a southwestern Atlantic temperate estuary. Journal of Plankton Research 27:1103-1111.

Barton, A. D., B. A. Ward, R. G. Williams, and M. J. Follows. 2014. The impact of fine $\square$ scale turbulence on phytoplankton community structure. Limnology and Oceanography: Fluids and Environments 4:34-49.

Bever, A. J., M. L. MacWilliams, and D. K. Fullerton. 2018. Influence of an observed decadal decline in wind speed on turbidity in the San Francisco Estuary. Estuaries and Coasts.

Boenigk, J. and G. Novarino. 2004. Effect of suspended clay on the feeding and growth of bacterivorous flagellates and ciliates. Aquatic Microbial Ecology 34:181-192.

Boltovskoy, D. 1981. Atlas del zooplancton del Atlántico Sudoccidental y métodos de trabajo con el zooplancton marino. Instituto Nacional de Investigación y Desarrollo Pesquero Mar del Plata.

Boyd, P. W. and D. A. Hutchins. 2012. Understanding the responses of ocean biota to a complex matrix of cumulative anthropogenic change. Marine Ecology Progress Series 470:125-135.

Brand, A., J. R. Lacy, K. Hsu, D. Hoover, S. Gladding, and M. T. Stacey. 2010. Windenhanced resuspension in the shallow waters of South San Francisco Bay: Mechanisms and potential implications for cohesive sediment transport. Journal of Geophysical Research: Oceans 115.

Breiman, L., J. Friedman, C. Stone, and R. Olshen. 1984. Classification and Regression Trees. CRC Press, New York.

Brendel, A. S., M. S. Dutto, M. C. Menéndez, M. A. H. Cisneros, and M. C. Piccolo. 2017. Wind Pattern Change Along a Period of Coastal Occurrence Variation of a Stinging Medusa on a SW Atlantic Beach. Anuário do Instituto de Geociências - UFRJ 40:303-315.

Calbet, A. and E. Saiz. 2005. The ciliate-copepod link in marine ecosystems. Aquatic Microbial Ecology 38:157-167.

Cardoso, L. d. S. and D. d. Motta Marques. 2009. Hydrodynamics-driven plankton community in a shallow lake. Aquatic Ecology 43:73-84.

Clamp, J. C. and D. H. Lynn. 2017. Investigating the biodiversity of ciliates in the 'Age of Integration'. Eur J Protistol 61:314-322.

Connell, J. H. 1978. Diversity in tropical rain forests and coral reefs. Science 199:13021310.

Craft, C., J. Clough, J. Ehman, S. Joye, R. Park, S. Pennings, H. Guo, and M. Machmuller. 2009. Forecasting the effects of accelerated sea-level rise on tidal marsh ecosystem services. Frontiers in Ecology and the Environment 7:73-78. 
Cho, H. J. 2007. Effects of prevailing winds on turbidity of a shallow estuary. International Journal of Environmental Research and Public Health 4:185-192.

De'ath, G. and K. E. Fabricius. 2000. Classification and regression trees: a powerful yet simple technique for ecological data analysis. Ecology 81:3178-3192.

Diodato, S. L. and M. S. Hoffmeyer. 2008. Contribution of planktonic and detritic fractions to the natural diet of mesozooplankton in Bahía Blanca Estuary. Hydrobiologia 614:83-90.

Dolan, J. R. 2010. Morphology and ecology in tintinnid ciliates of the marine plankton: correlates of lorica dimensions. Acta Protozoologica 2010:235-244.

Dolan, J. R. and C. L. Gallegos. 2001. Estuarine diversity of tintinnids (planktonic ciliates). Journal of Plankton Research 23:1009-1027.

Dolan, J. R., R. W. Pierce, E. J. Yang, and S. Y. Kim. 2012. Southern ocean biogeography of tintinnid ciliates of the marine plankton. J Eukaryot Microbiol 59:511-519.

Dragani, W. C., P. B. Martin, C. G. Simionato, and M. I. Campos. 2010. Are wind wave heights increasing in south-eastern south American continental shelf between $32^{\circ} \mathrm{S}$ and $40^{\circ} \mathrm{S}$ ? Continental Shelf Research 30:481-490.

Elith, J., J. R. Leathwick, and T. Hastie. 2008. A working guide to boosted regression trees. Journal of Animal Ecology 77:802-813.

Fogt, R. L., D. H. Bromwich, and K. M. Hines. 2011. Understanding the SAM influence on the South Pacific ENSO teleconnection. Climate Dynamics 36:1555-1576.

Gaedeke, A. and U. Sommer. 1986. The influence of the frequency of periodic disturbances on the maintenance of phytoplankton diversity. Oecologia 71:25-28.

Guinder, V. A., M. C. López-Abbate, A. A. Berasategui, V. L. Negrin, G. Zapperi, P. D. Pratolongo, M. D. Fernández Severini, and C. A. Popovich. 2015. Influence of the winter phytoplankton bloom on the settled material in a temperate shallow estuary. Oceanologia 57:50-60.

Guinder, V. A., C. A. Popovich, J. C. Molinero, and G. M. Perillo. 2010. Long-term changes in phytoplankton phenology and community structure in the Bahía Blanca Estuary, Argentina. Marine Biology 157:2703-2716.

Hasle, G. R. 1978. The inverted microscope method. Pages 88-96 in A. Sournia, editor. Phytoplankton Manual. UNESCO, Paris.

Heger, T. J., V. P. Edgcomb, E. Kim, J. Lukes, B. S. Leander, and N. Yubuki. 2014. A resurgence in field research is essential to better understand the diversity, ecology, and evolution of microbial eukaryotes. J Eukaryot Microbiol 61:214-223.

Hingsamer, P., F. Peeters, and H. Hofmann. 2014. The consequences of internal waves for phytoplankton focusing on the distribution and production of Planktothrix rubescens. PLoS One 9:e104359.

Jack, J. D. and J. J. Gilbert. 1993. The effect of suspended clay on ciliate population growth rates. Freshw Biol 29:385-394.

Kammerlander, B., K. A. Koinig, E. Rott, R. Sommaruga, B. Tartarotti, F. Trattner, and B. Sonntag. 2016. Ciliate community structure and interactions within the planktonic food web in two alpine lakes of contrasting transparency. Freshw Biol 61:19501965.

Keller, D. P. and R. R. Hood. 2011. Modeling the seasonal autochthonous sources of dissolved organic carbon and nitrogen in the upper Chesapeake Bay. Ecological modelling 222:1139-1162.

Kiørboe, T. 2008. A mechanistic approach to plankton ecology. Princeton University Press. 
Kiørboe, T. and E. Saiz. 1995. Planktivorous feeding in calm and turbulent environments, with emphasis on copepods. Marine Ecology Progress Series 122:135-145.

Kirwan, M. L. and J. P. Megonigal. 2013. Tidal wetland stability in the face of human impacts and sea-level rise. Nature 504:53.

Kreyling, J., A. H. Schweiger, M. Bahn, P. Ineson, M. Migliavacca, T. Morel-Journel, J. R. Christiansen, N. Schtickzelle, and K. S. Larsen. 2018. To replicate, or not to replicate - that is the question: how to tackle nonlinear responses in ecological experiments. Ecol Lett $\mathbf{0}$.

Lanfredi, N. W., E. E. D'Onofrio, and C. A. Mazio. 1988. Variations of the mean sea level in the southwest Atlantic Ocean. Continental Shelf Research 8:1211-1220.

Laspoumaderes, C., M. S. Souza, B. Modenutti, and E. Balseiro. 2017. Glacier melting and response of Daphnia oxidative stress. Journal of Plankton Research 39:675-686.

Legendre, L. and R. B. Rivkin. 2015. Flows of biogenic carbon within marine pelagic food webs: Roles of microbial competition switches. Marine Ecology Progress Series 521:19-30.

Li, Y. and M. Li. 2011. Effects of winds on stratification and circulation in a partially mixed estuary. Journal of Geophysical Research: Oceans 116.

López-Abbate, M. C., J. C. Molinero, V. A. Guinder, M. S. Dutto, M. S. Barria de Cao, L. A. Ruiz Etcheverry, R. E. Pettigrosso, M. C. Carcedo, and M. S. Hoffmeyer. 2015. Microplankton dynamics under heavy anthropogenic pressure. The case of the Bahia Blanca Estuary, southwestern Atlantic Ocean. Mar Pollut Bull 95:305-314.

López-Abbate, M. C., J. C. Molinero, V. A. Guinder, G. M. E. Perillo, R. H. Freije, U. Sommer, C. V. Spetter, and J. E. Marcovecchio. 2017. Time-varying environmental control of phytoplankton in a changing estuarine system. Science of The Total Environment 609:1390-1400.

López Cazorla, A., R. Pettigrosso, L. Tejera, and R. Camina. 2011. Diet and food selection by Ramnogaster arcuata (Osteichthyes, Clupeidae). Journal of fish biology 78:20522066.

Lorenzen, C. J. 1967. Determination of chlorophyll and pheo-pigments: Spectrophotometric equations. Limnology and Oceanography 12:343-346.

Marshall, G. J. 2003. Trends in the Southern Annular Mode from observations and reanalyses. Journal of Climate 16:4134-4143.

Martínez, R. A., A. Calbet, and E. Saiz. 2017. Effects of small-scale turbulence on growth and grazing of marine microzooplankton. Aquatic Sciences 80:2.

Menéndez, C. G. and A. F. Carril. 2010. Potential changes in extremes and links with the Southern Annular Mode as simulated by a multi-model ensemble. Climatic change 98:359-377.

Mitra, A., K. J. Flynn, J. M. Burkholder, T. Berge, A. Calbet, J. A. Raven, E. Granéli, P. M. Glibert, P. J. Hansen, D. K. Stoecker, F. Thingstad, U. Tillmann, S. Våge, S. Wilken, and M. V. Zubkov. 2014. The role of mixotrophic protists in the biological carbon pump. Biogeosciences 11:995-1005.

Moreno-Ostos, E., L. Cruz-Pizarro, A. Basanta, and D. G. George. 2008. The influence of wind-induced mixing on the vertical distribution of buoyant and sinking phytoplankton species. Aquatic Ecology 43:271-284.

Palma, E. D., R. P. Matano, A. R. Piola, and L. E. Sitz. 2004. A comparison of the circulation patterns over the Southwestern Atlantic Shelf driven by different wind stress climatologies. Geophysical Research Letters 31. 
Pécseli, H., J. Trulsen, and Ø. Fiksen. 2014. Predator-prey encounter and capture rates in turbulent environments. Limnology and Oceanography: Fluids and Environments 4:85-105.

Perillo, G. M. 1995. Geomorphology and sedimentology of estuaries. Elsevier.

Perillo, G. M. E. 2009. Tidal courses: classification, origin and functionality. Pages 185210 in G. M. E. Perillo, E. Wolanski, D. R. Cahoon, and M. M. Brinson, editors. Coastal Wetlands: An Integrated Ecosystem Approach. Elsevier, Amsterdam.

Perillo, G. M. E., M. C. Piccolo, E. Parodi, and R. H. Freije. 2001. The Bahia Blanca Estuary, Argentina. Pages 205-217 in U. Seeliger and B. Kjerfve, editors. Coastal Marine Ecosystems of Latin America. Springer Berlin Heidelberg, Berlin, Heidelberg.

Perillo, G. M. E. and M. E. Sequeira. 1989. Geomorphologic and sediment transport characteristics of the middle reach of the Bahia Blanca estuary (Argentina). Journal of Geophysical Research: Oceans 94:14351-14362.

Pettigrosso, R. E. 2003. Planktonic ciliates Choreotrichida and Strombidiida from the inner zone of Bahía Blanca Estuary, Argentina. Iheringia, Série Zoolgia 93:117-126.

Piccolo, M., G. Perillo, and W. Melo. 2008. The Bahía Blanca Estuary: an integrated overview of its geomorphology and dynamics. Pages 221-232. IST Scientific Publishers, Lisbon (Portugal).

Piccolo, M. C. and G. M. E. Perillo. 1990. Physical characteristics of the Bahia Blanca estuary (Argentina). Estuarine, Coastal and Shelf Science 31:303-317.

Pratolongo, P., C. Mazzon, G. Zapperi, M. J. Piovan, and M. M. Brinson. 2013. Land cover changes in tidal salt marshes of the Bahía Blanca estuary (Argentina) during the past 40 years. Estuarine, Coastal and Shelf Science 133:23-31.

Pratolongo, P., M. J. Piovan, D. G. Cuadrado, and E. A. Gómez. 2017. Coastal landscape evolution on the western margin of the Bahía Blanca Estuary (Argentina) mirrors a non-uniform sea-level fall after the mid-Holocene highstand. Geo-Marine Letters 37:373-384.

Pratolongo, P. D., G. M. E. Perillo, and M. C. Piccolo. 2010. Combined effects of waves and plants on a mud deposition event at a mudflat-saltmarsh edge in the Bahía Blanca estuary. Estuarine, Coastal and Shelf Science 87:207-212.

R Development Core Team. 2014. R: A language and environment for statistical computing.

Reisinger, A., J. C. Gibeaut, and P. E. Tissot. 2017. Estuarine suspended sediment dynamics: Observations derived from over a decade of satellite data. Frontiers in Marine Science 4.

Reynolds, C. S. 2006. The ecology of phytoplankton. Cambridge University Press.

Scully, M. E., C. Friedrichs, and J. Brubaker. 2005. Control of estuarine stratification and mixing by wind-induced straining of the estuarine density field. Estuaries 28:321326.

Simionato, C. G., C. S. Vera, and F. Siegismund. 2005. Surface wind variability on seasonal and interannual scales over Río de la Plata area. Journal of Coastal Research 21:770-783.

Sommaruga, R. and G. Kandolf. 2014. Negative consequences of glacial turbidity for the survival of freshwater planktonic heterotrophic flagellates. Sci Rep 4:4113.

Spetter, C. V., C. A. Popovich, A. Arias, R. O. Asteasuain, R. H. Freije, and J. E. Marcovecchio. 2015. Role of nutrients in phytoplankton development during a 
winter diatom bloom in a eutrophic South American estuary (Bahía Blanca, Argentina). Journal of Coastal Research 31:76-87.

Steinberg, D. K. and M. R. Landry. 2017. Zooplankton and the ocean carbon cycle. Ann Rev Mar Sci 9:413-444.

Sun, X., K. H. Cook, and E. K. Vizy. 2017. The South Atlantic Subtropical High: Climatology and Interannual Variability. Journal of Climate 30:3279-3296.

Trenberth, K. E. 1997. The definition of el nino. Bulletin of the American Meteorological Society 78:2771-2778.

Venegas, S. A., L. A. Mysakand, and D. N. Straub. 1996. Evidence for interannual and interdecadal climate variability in the South Atlantic. Geophysical Research Letters 23:2673-2676.

Vera, C., G. Silvestri, V. Barros, and A. Carril. 2004. Differences in el nino response over the southern hemisphere. Journal of Climate 17:1741-1753.

Weir, D. and J. McManus. 1987. The role of wind in generating turbidity maxima in the Tay estuary. Continental Shelf Research 7:1315-1318.

Whipple, A. C., R. A. Luettich, J. V. Reynolds-Fleming, and R. H. Neve. 2018. Spatial differences in wind-driven sediment resuspension in a shallow, coastal estuary. Estuarine, Coastal and Shelf Science 213:49-60.

Wohlers, J., A. Engel, E. Zollner, P. Breithaupt, K. Jurgens, H. G. Hoppe, U. Sommer, and U. Riebesell. 2009. Changes in biogenic carbon flow in response to sea surface warming. Proc Natl Acad Sci U S A 106:7067-7072.

Wolfe, A. M., S. E. Allen, M. Hodal, R. Pawlowicz, B. P. Hunt, and D. Tommasi. 2015. Impact of advection loss due to wind and estuarine circulation on the timing of the spring phytoplankton bloom in a fjord. ICES Journal of Marine Science 73:15891609.

Yeo, S.-R. and K.-Y. Kim. 2015. Decadal changes in the Southern Hemisphere sea surface temperature in association with El Niño-Southern Oscillation and Southern Annular Mode. Climate Dynamics 45:3227-3242.

Zapperi, G., M. J. Piovan, and P. Pratolongo. 2017. Community structure and spatial zonation of benthic macrofauna in mudflats of the Bahía Blanca Estuary, Argentina. Journal of Coastal Research 0:null.

Zapperi, G., P. Pratolongo, M. J. Piovan, and J. E. Marcovecchio. 2016. Benthic-Pelagic coupling in an intertidal mudflat in the Bahía Blanca Estuary (SW Atlantic). Journal of Coastal Research 32:629-637.

Zhou, J., B. Qin, C. Casenave, X. Han, G. Yang, T. Wu, P. Wu, and J. Ma. 2015. Effects of wind wave turbulence on the phytoplankton community composition in large, shallow Lake Taihu. Environmental Science and Pollution Research 22:1273712746. 


\section{ACCEPTED MANUSCRIPT}
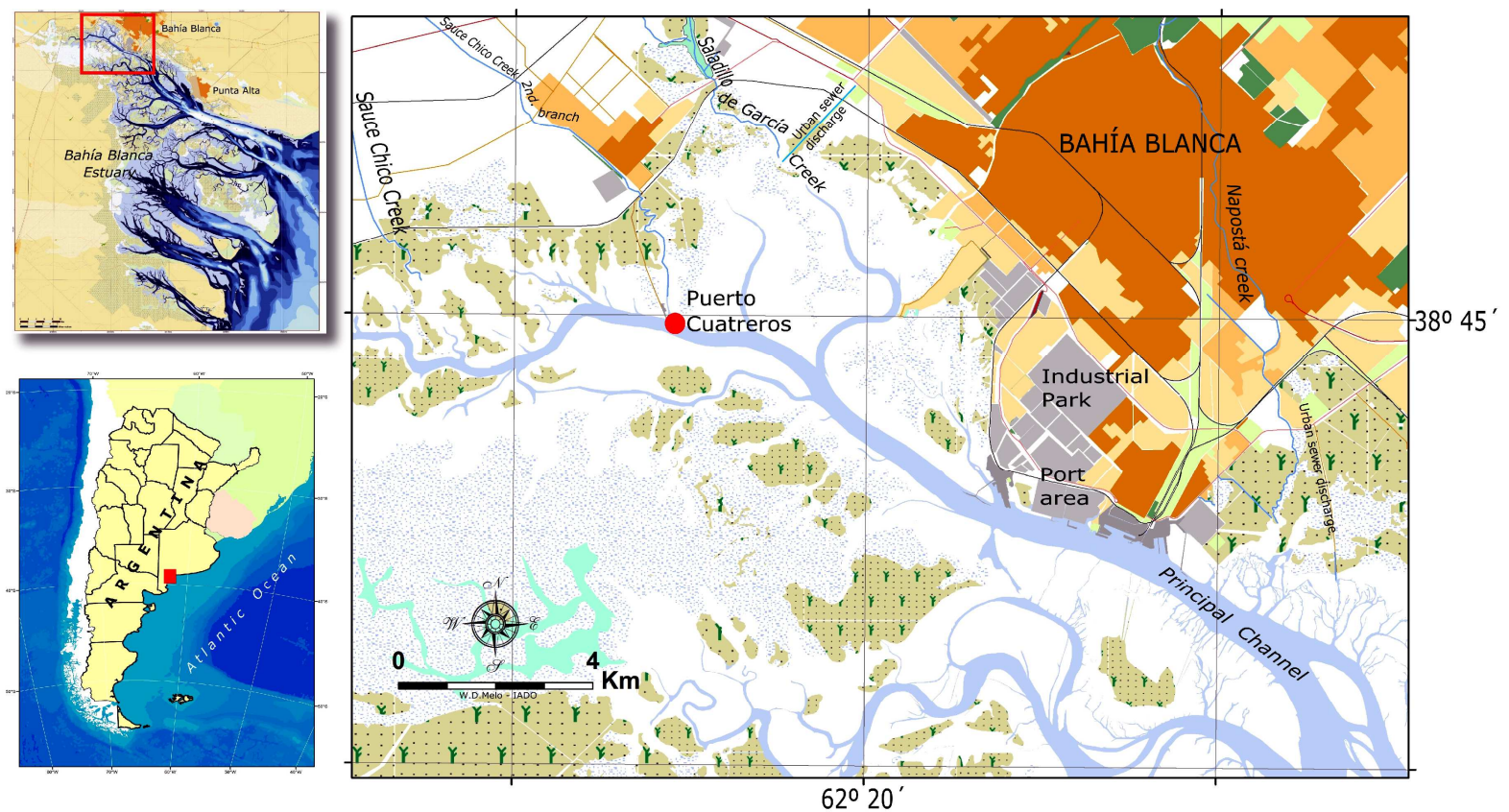

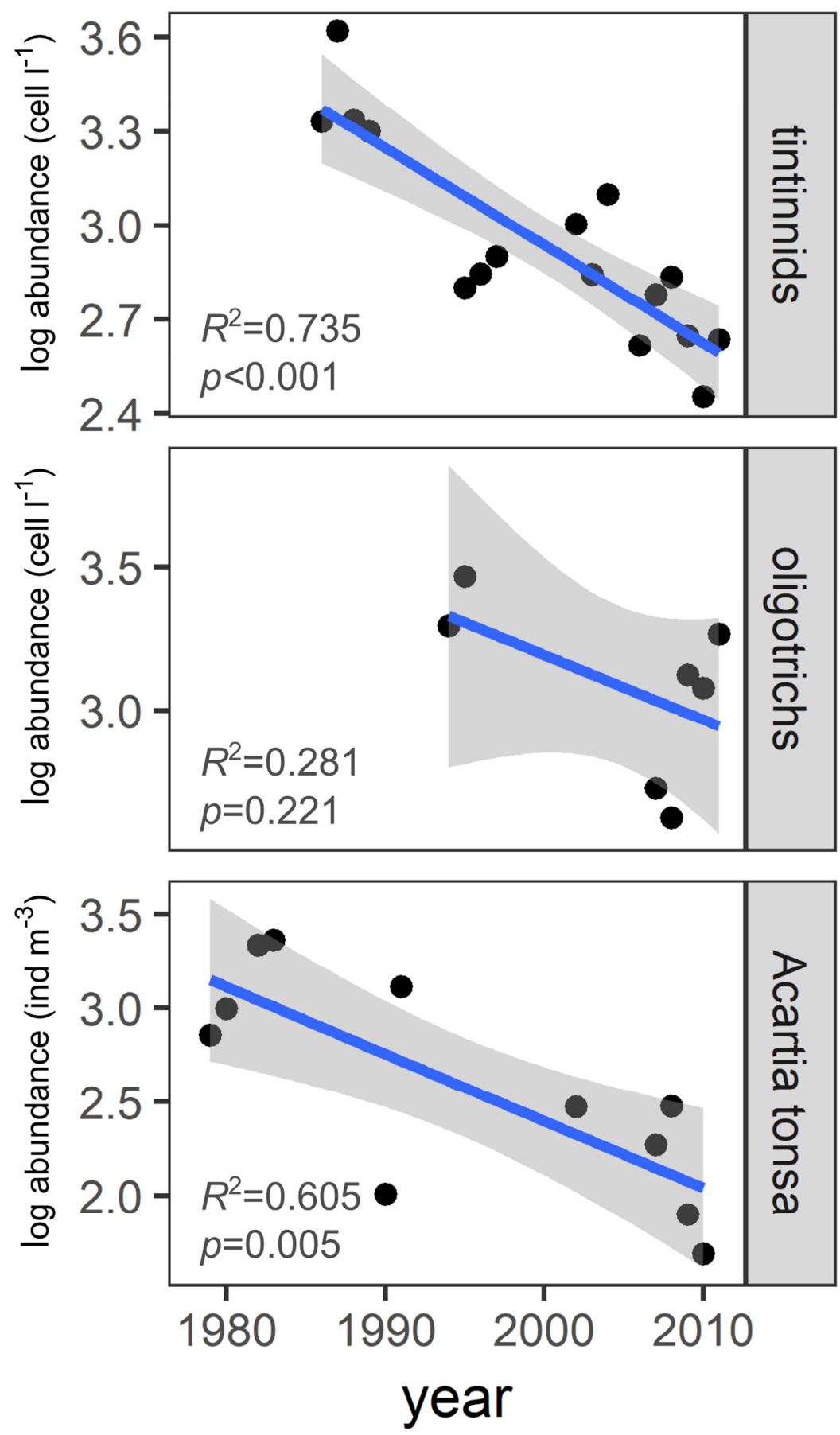


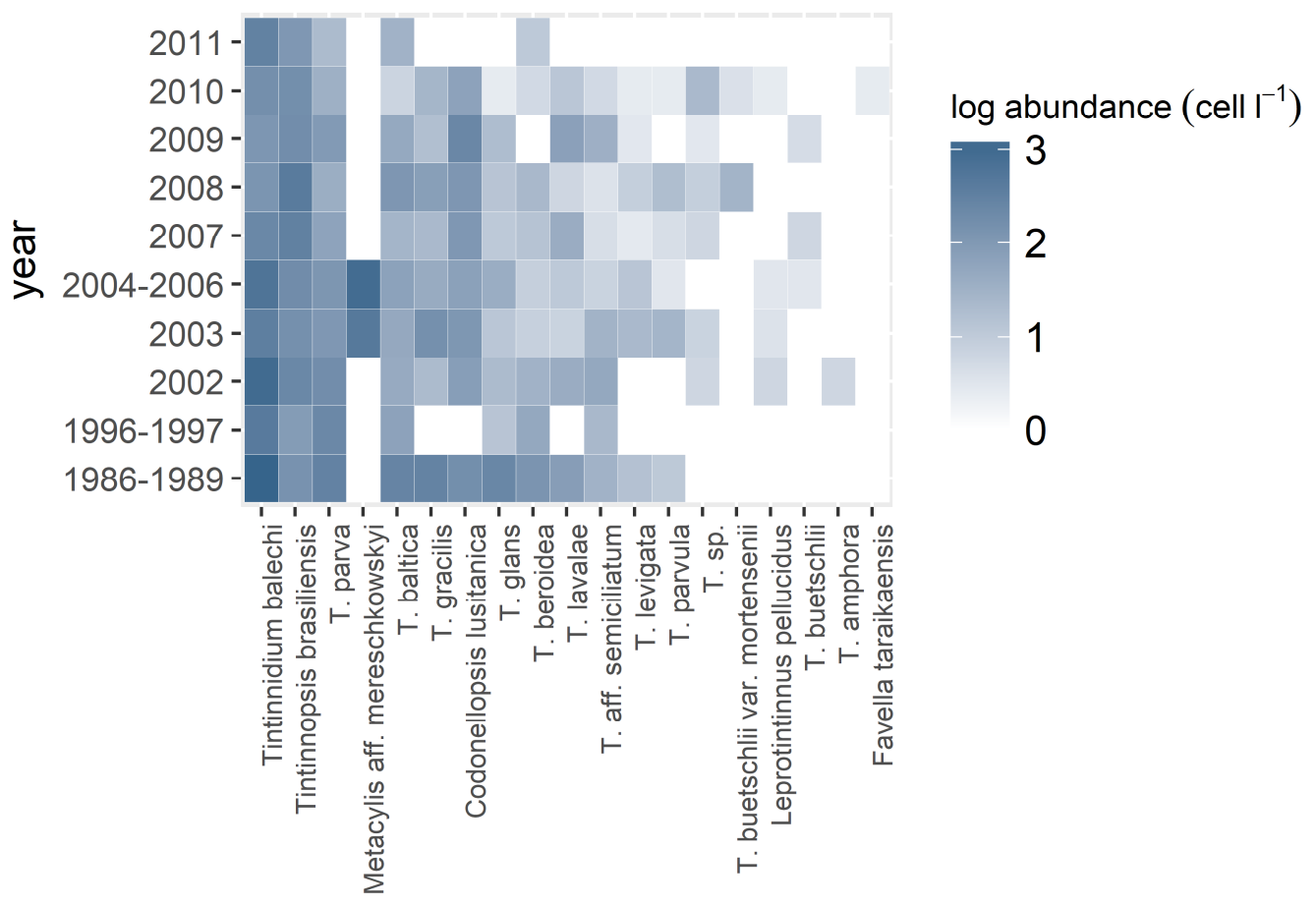




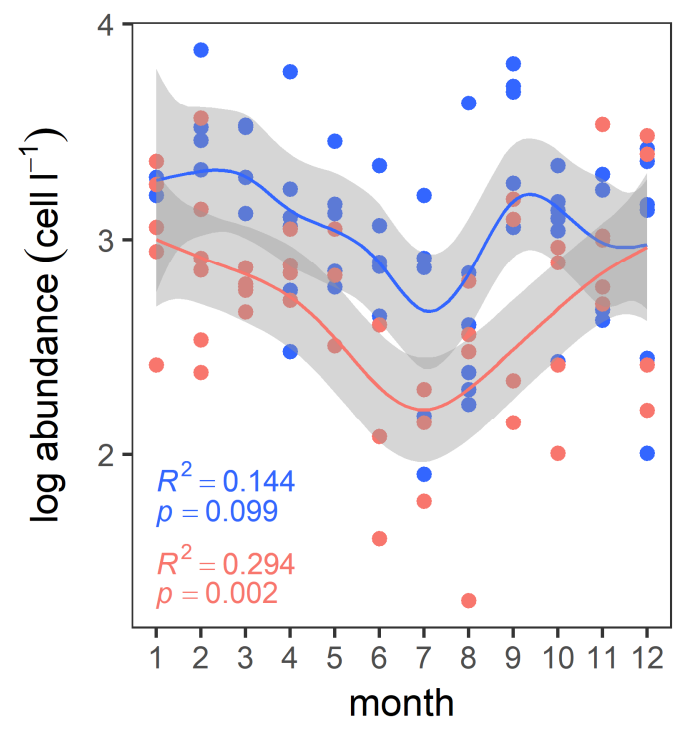

period

$\rightarrow 1986-2002$

2003-2011 

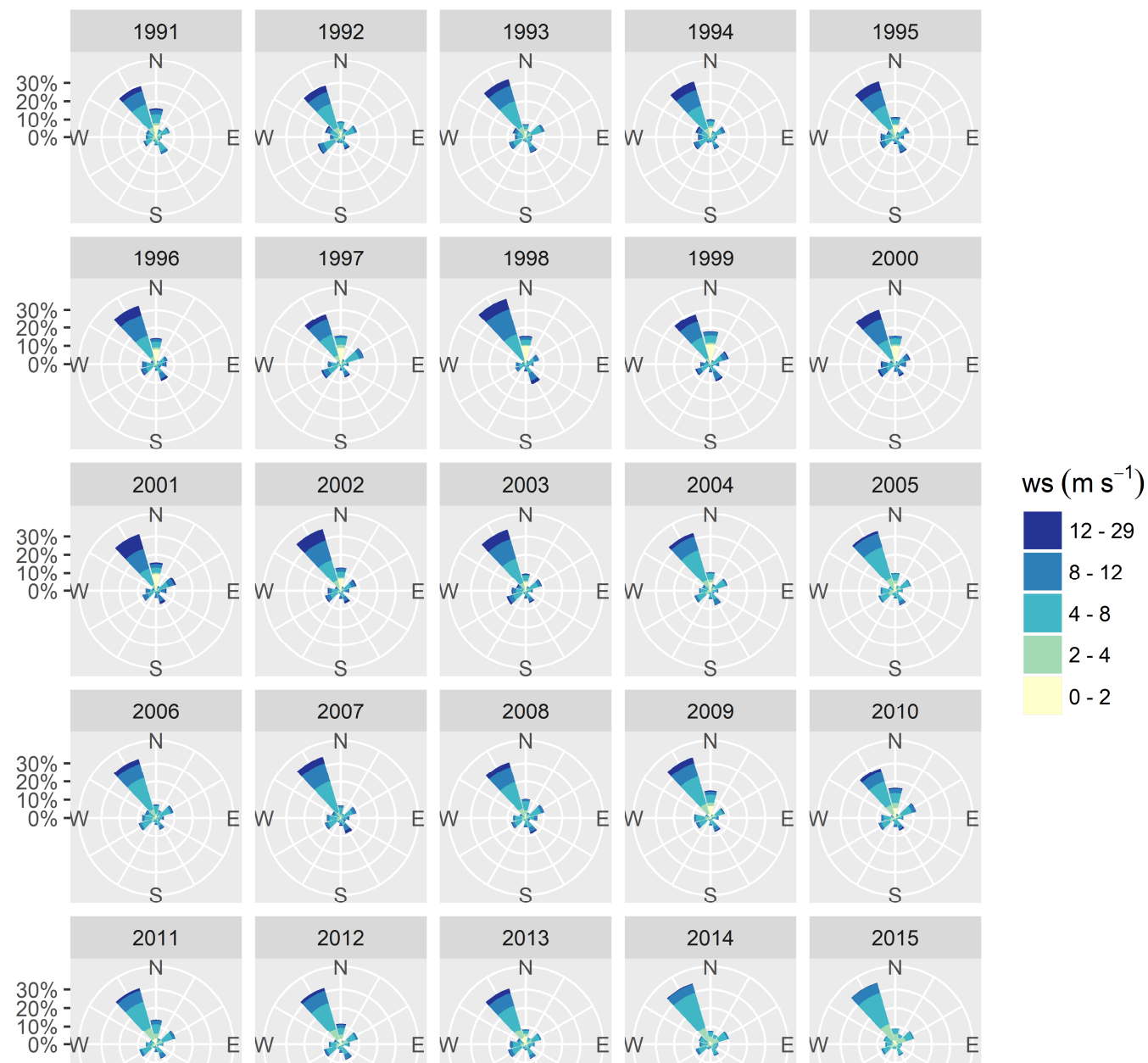

S

S

S

S

S 


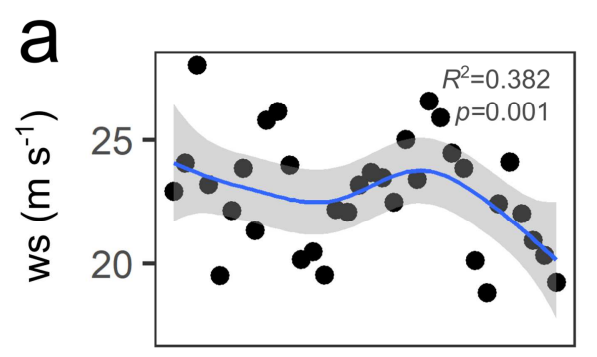

b
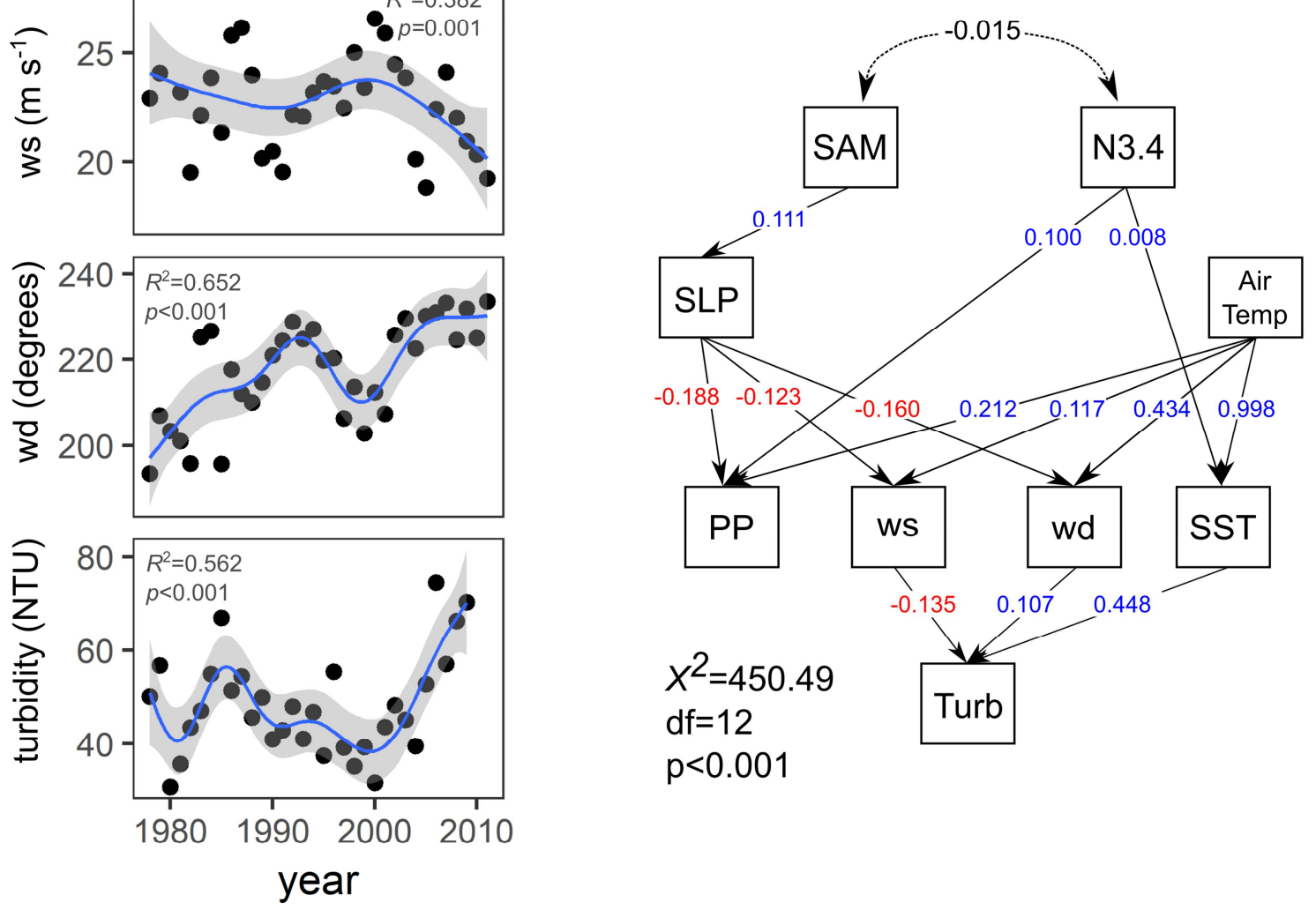

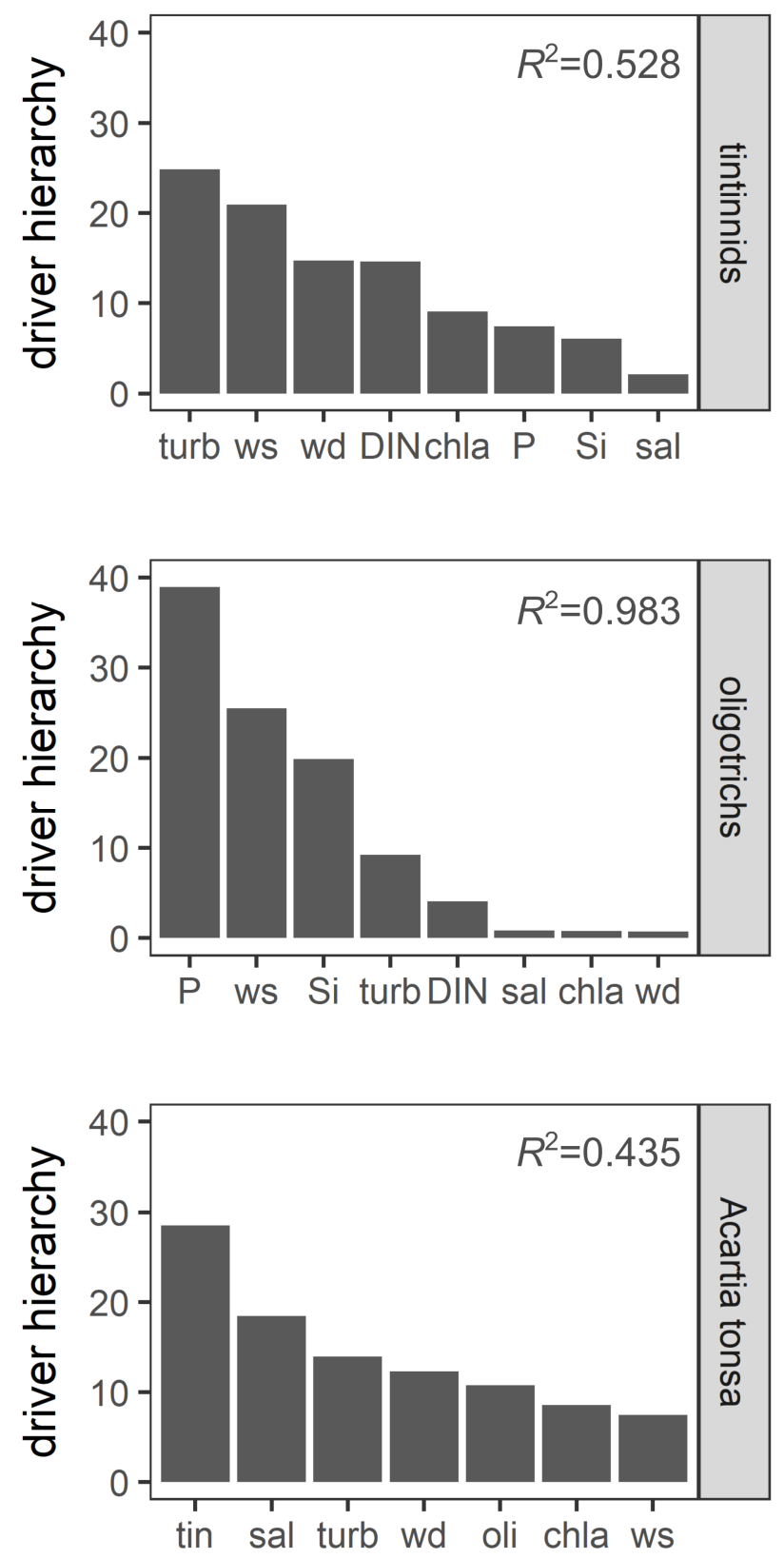

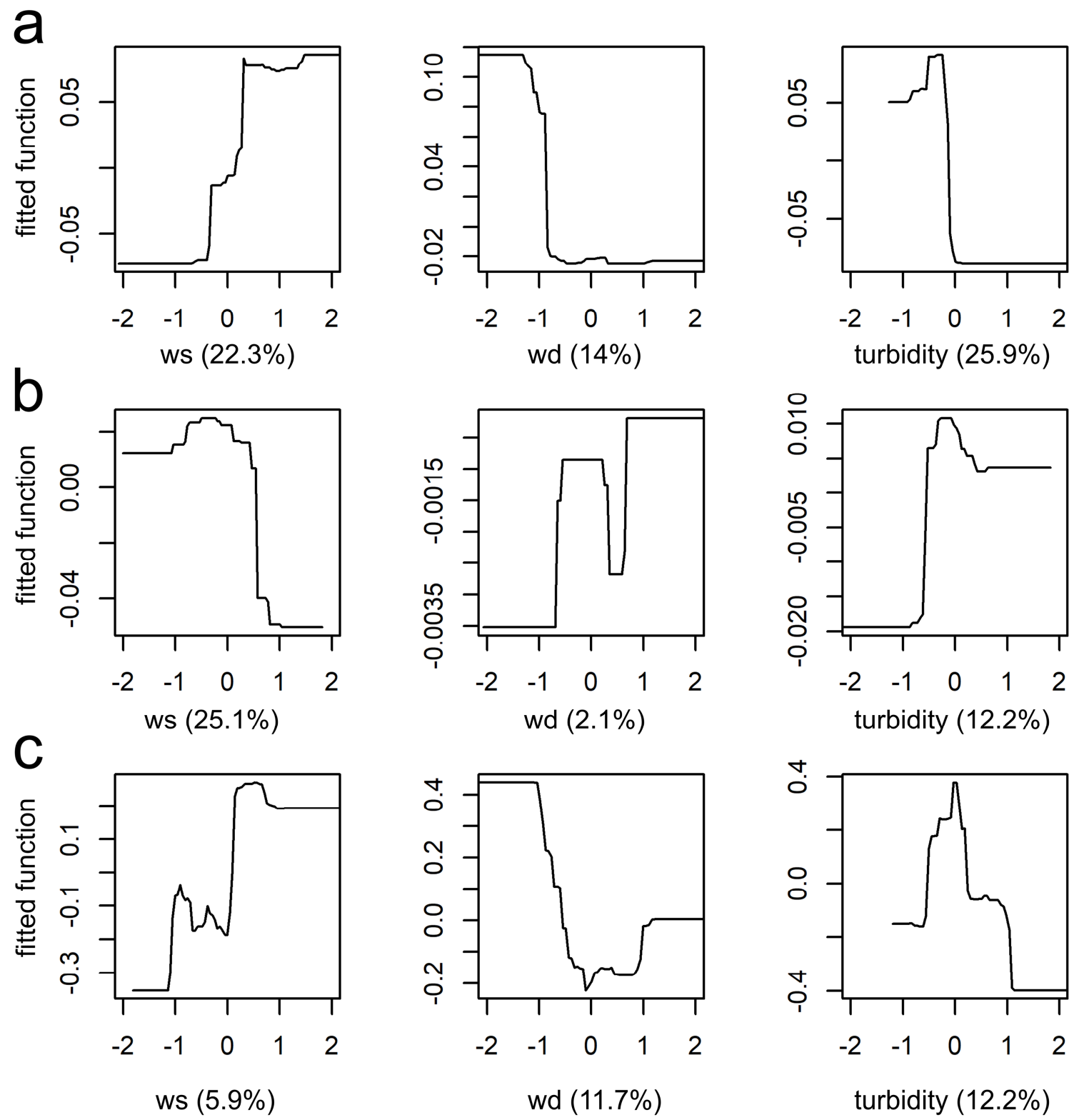
-Planktonic ciliate's abundance decreased over the last 25 years in a shallow estuary.

-Decreasing cell abundance was linked to changes in wind dominant regimes and increased water turbidity.

-Tintinnids were more vulnerable to wind patterns and turbidity and lost synchrony with primary productivity.

-Interannual variability of the copepod Acartia tonsa followed the changes in ciliate community.

-Erosive processes in shallow estuaries impact on the interannual dynamics of ciliates and such effects can cascade-up to copepods. 